\title{
Innovative Leadership by School Principals: Embedding Information Communication and Technology in Kuwaiti Schools
}

Mohammed Al Sharija, Ph.D., Ministry of Education, Kuwait

James J Watters, Ph.D., Queensland University of Technology, Australia

\begin{abstract}
Kuwait is an oil rich country planning for a future that is not dependent on exploiting natural resources. A major policy initiative has been the introduction of Information Communication and Technology (ICT) to schools. However, contextual issues and teacher capabilities in the use of ICT have limited the success of this initiative. The study examines the leadership strategies of two secondary school principals whose schools have achieved this goal. The case study draws on intensive data collected through interviews of the principals, and teachers supported by document analysis and observations. Analysis was guided by theoretical perspectives drawn from the literature which identified a range of strategies used by the principals to manage change. The principals of Schools A and B employed three key strategies to maximise the impact on the teaching staff incorporating ICT into their teaching and learning practices. These strategies were: (a) encouragement for teaching staff to implement ICT in their teaching; (b) support to meet the material and human needs of teaching staff using ICT; and (c) provision of instructions and guidance for teaching staff in how and why such behaviours and practices should be performed. The outcome of this study proposes an innovative change leadership model that informs emerging countries, which are also undergoing major change related to ICT. However, the study also revealed limitations in the implementation of ICT in the classroom and provides insights into further strategies that principals need to adopt.
\end{abstract}

Keywords: ICT Implementation in Education; Educational Leadership Practices; Kuwaiti Education

\section{BACKGROUND}

dvances in Information Communication and Technology (ICT) over the past thirty years have "changed the way people live, work, and play" (Kozma, 2005, p. 2). A technology catalysed expansion of communication has meant that knowledge is the currency of international trade and commerce (De Ferranti, Perry, Lederman, \& Maloney, 2002). The rise in knowledge intensity is being driven by the combined forces of the information technology revolution and the increasing pace of technological change in science, engineering and medicine (Saunders, Brynjolfsson, LoBue, Meyer, \& Samuel, 2007). A knowledge-based economy uses knowledge to create and support new economies that are not based on the assembly line industrialisation or exploitation of natural resources. Instead, emerging economies depend significantly on intellectual productivity (Beach, 2003). Kozma argues social improvement and economic development will require the creation of policies and programs that increase the impact of ICT on education (e.g., Kozma, 2010). As a stimulus to enhance learning and management of schools, Kuwait has responded to this challenge by introducing policies to build the country's technological infrastructure in schools and develop teacher capabilities in using ICT (Ministry of Education in Kuwait, 2002). An early initiative was the mandate that principals and teachers obtain an International Computer Driving Licence (ICDL) (ECDL Foundation, 2008). According to the Kuwaiti Ministry of Education plan (Ministry of Education, 2007), ICT will be incorporated into all schools' curriculum, decisionmaking processes, and that databases must be established for all schools. Such plans are aimed at resourcing teachers, improving teaching practices and to reform the curriculum so that ICT can be used as tools for learning. It 
is expected that students will be able to use ICT to engage in inquiry learning, access digital information and develop their higher level cognitive skills. These plans are premised on the assumption that increasing the technological capacity of students will enable them to contribute to economic progress in a knowledge base economy. The Ministry of Education through its ICT plans hopes to create a new economic sector of industries and services that are related to ICT by developing students' ICT capacities and skills by 2025 .

\section{LITERATURE BACKGROUND}

Several contemporary research studies have shown that the implementation of ICT brings about meaningful change in teaching practices (Levin \& Wadmany, 2008; Tondeur, Devos, Houtteb, Braaka, \& Valckea, 2009). Although this evolution towards ICT may sound like common sense, Creighton (2003) stresses that the changes associated with ICT implementation can be significant, and that this change is associated with behavioural adjustments and transformations. However, it is also recognised that applications of ICT are often pedagogically unsophisticated being limited to the use of presentation software, datasources and management tools that reinforce existing teaching practices rather than to reform practice and support student inquiry and collaboration (Harris, Mishra \& Koehler, 2009). To achieve optimal uptake of ICT, as implicitly suggested by Fullan (2007) and Rogers (2003), change must be led by effective leaders. Naturally, in the case of schools, the formal leader is the principal. Hence, in order to successfully implement ICT into schools, and to avoid failure (Gichoya, 2005), school principals; as change agents; need to effectively lead the ICT implementation processes. To achieve teaching reform principals need to go beyond being change managers to become "learning leaders" (duFour \& Marzano, 2009). As learning leaders they not only are able to support and facilitate the uptake of ICT but can impact and guide the appropriate use of that technology to reform teaching. According to the mandated policy, Kuwaiti principals have responsibility for embedding ICT (Ministry of Education in Kuwait, 2002). However, According to Ablah Alaisa (personal communication, July, 13, 2008), the General Manager of Training and Human Development in the Ministry of Education, only about $5 \%$ of principals in Kuwait have demonstrated satisfactory use of, for example, email to communicate in schools. This statement indicates that principals in Kuwait are facing difficulties in managing the ICT implementation.

It has been argued that the role assumed and the practices exercised by a leader are the most powerful factors in embedding ICT change. For example, Ma's (2003) case study identified that the school principal is a significant figure for embedding ICT. The roles of school principals in leading change (either positively or negatively) were documented to influence the final ICT implementation, as well as impacting the implementation process in a number of studies (Ely, 1990; 1999; Fullan, 2001; Schiller, 2002). All these studies have shown that school principals play a significant role as agents of change when facilitating ICT adoption. Therefore, this paper describes a model comprising five components of effective leadership practices has been constructed from the literature around leadership. This model largely relied on Successful school leadership: What it is and how it influences pupil learning work (Leithwood, Sammons, Hopkins \& Harris, 2006). The five components are:

1. $\quad$ Finance management (i.e., Managing budget, Managing maintenance and ICT infrastructure) (MendezMorse, 1992; Mumford \& Licuanan, 2004; Yee, 1999)

2. Setting direction (i.e., Building shared vision, Fostering agreement, Motivating staff, Setting high expectations) (Covington, 2000; LaBonte, 2005; Leithwood et al., 2006)

3. Building collaboration (i.e., Building collaborative culture, Building teams, Solving problems, Connecting school with other schools) (Albanese, 1994; Fullan, 2007; Holleran, 1997; Leithwood et al., 2006; Yee, 1999)

4. Principal Agency (i.e., Principal ICT competences, Providing guidance to link ICT into pedagogy, Sustaining ICT change) (LaBonte, 2005; Creighton, 2003; Jegede, Dibu-Ojerinde, \& Ilori, 2007)

5. Developing staff (i.e., providing individual consideration, Providing individual PD opportunities, Supervising PD activities, Providing an appropriate model, leading learning) (Deci \& Ryan, 2002; Leithwood et al., 2006; Leung, Watters, \& Ginns, 2005; Mendez- Morse, 1992; Yee, 1999; Mohammad, Manssour, \& Wegerif, 2011)

This initial model was used to guide the planning of data collection and data analysis. Since principals have been seen as critical player in embedding ICT, there has been a call for further research into effective leadership 
practices for embedding ICT in schools has been identified by a number of researchers (e.g., Anderson \& Dexter, 2005; Schiller, 2003; Wilmore \& Betz, 2000), therefore, this study aimed to examine the role of principals in leading and managing change in the use of ICT in schools.

\section{AIMS OF THE RESEARCH}

The aim of this study was twofold:

1. To document the leadership practices of principals in leading and managing change in the uptake of ICT in schools.

2. To document how principals adopted learning leadership roles in supporting staff to adopt ICT in their practices.

\section{DESIGN OF THE STUDY}

This case study profiles two Kuwaiti secondary schools; both schools had well established ICT programs and were nominated by the Ministry of Education in Kuwait as leading schools in embedding ICT. Following Yin's (2009) recommendation on sourcing rich data, four data sources were utilised in this study, namely: (1) interview; (2) observation; (3) questionnaire; and (4) documents analysis. Two school principals were individually interviewed as well as five teachers from each of their schools (A \& B) were randomly selected and a focus group interview was conducted. Thematic analysis approach was employed in analysing the data. The data base comprised transcribed interview data, open ended questionnaire responses, researcher notes taken during observations and policy and interschool communication documents. The data were examined line by line and codes drawn from the theoretical model described above assigned. Anomlalies were noted and new codes developed as required. Codes were subsequently condensed into themes illustrative o the major components of the model.

\section{FINDINGS}

Both participating principals claimed to demonstrate the five constructed components. Table 1 below represents a summary of the principals' claims in displaying their leadership practices. As shown in Table 1, both principals used strategies that enhance ICT adoption among staff. Following quotations are representative quotes capturing a general response of participating principals and teachers. For example, Principal of School A claimed to provide individual consideration opportunities preceding that:

As you know there were some older teachers who had difficulties to absorb the new ICT skills, it was not easy to convince them, but through discussion, persuasion, the exchange of ideas, offer alternatives, give examples and provide support, they interacted and started to explore and experiment the new technology. These actions provided stimulation influence on all teachers to employ ICT in their tasks (Lines: 38-43 P/A).

Thus, the Principal A (P/A) recognised that some older teachers had difficulty in learning new skills. However, he claimed to follow a strategy encompassing discussion, persuasion, the exchanging of ideas, offering alternatives, giving examples, and providing support to solve such constraints. He asserted that this strategy helped in solving some teachers' difficulties with ICT through a variety of supports. An example of Principal A effective strategies is when he explained how he solved group problem stating that:

There used to be an overlap in some of the tasks related to technology, so I met with an Educational Technology Specialist and the Department of Computer staff and have distributed tasks responsibilities...it was solved through meeting with the staff and listening to their views and discuss the responsibilities, and then we reached a consensual agreement on the mechanism of actions and responsibilities of each parties on ICT in the school (P/A-Q).

Hence, through the Principal's interest in finding solutions to the problems, his strategy reflects a genuine desire to improve performance and to find possible solutions to the problems. This Principal provided a practical example of his involvement in solving a problem between two parties or group problems. Such problems arose when tasks and responsibilities overlapped, significantly affecting the workflow. In such instances he would bring the staff 
together for a meeting to listen to their views, to gain an understanding of the problems, and to discuss where the responsibilities lay, until a consensual agreement was reached about the work mechanisms and the assigned responsibilities. These practices clearly show his desire to be directly involved in analysing and solving problems with the best solutions.

Table 1: Summary of participating principals' practices claims

\begin{tabular}{|c|c|c|}
\hline Component & Principal A & Principal B \\
\hline Finance Management & $\begin{array}{l}\text { - Sought support from donor "parent" to increase } \\
\text { the school income "taking risk". } \\
\text {-Prioritised the ICT infrastructure. } \\
\text {-Acknowledged constraints posed by MoE } \\
\text { regulations }\end{array}$ & $\begin{array}{l}\text {-Managed and organised financial support from } \\
\text { local. } \\
\text {-Prioritised the ICT infrastructure } \\
\text {-Acknowledged constraints posed by MoE } \\
\text { regulations }\end{array}$ \\
\hline Setting Direction & $\begin{array}{l}\text {-Discussed, encouraged, and supported central } \\
\text { ICT vision. } \\
\text { Went beyond communicating vision to be a key } \\
\text { promoter of the vision. } \\
\text {-Staff involved in decision-making. } \\
\text {-Closely working with all staff. }\end{array}$ & $\begin{array}{l}\text {-Planned, discussed and upheld the vision so that } \\
\text { the staff would gradually come on board and } \\
\text { embrace the ICT vision. } \\
\text {-Maintained the hierarchical organisation. } \\
\text {-Built interpersonal relationships with staff and } \\
\text { inspired their aspirations to learn about ICT. }\end{array}$ \\
\hline Building Collaboration & $\begin{array}{l}\text {-Encouraged collaborative culture in multiple } \\
\text { ways. } \\
\text {-Effectively solved problems. } \\
\text {-Built mutual plans related to ICT with other } \\
\text { principals. }\end{array}$ & $\begin{array}{l}\text {-Directly involved in organising collaborative } \\
\text { activities } \\
\text {-Worked according to the hierarchical system in } \\
\text { solving problems. } \\
\text {-Encouraged staff to maintain good relationships } \\
\text { with other schools. }\end{array}$ \\
\hline Principal Agency & $\begin{array}{l}\text {-Supported and coordinated activities between the } \\
\text { school's departments in relation to ICT matters to } \\
\text { facilities ICT use into teaching practices. } \\
\text {-Planned new ICT applications to be added into } \\
\text { the school program and encouraged the staff to } \\
\text { sustain their ICT practice. }\end{array}$ & $\begin{array}{l}\text {-Discussed how some ICT devices can be linked } \\
\text { to learning and teaching approaches. } \\
\text {-Added more ICT applications, planned ICT } \\
\text { reform, and encouraged creativity in using ICT } \\
\text { devices in order to sustain ICT changes. }\end{array}$ \\
\hline Developing Staff & $\begin{array}{l}\text {-Used multiple strategies to address the gap in } \\
\text { staff knowledge and skills. } \\
\text {-Personally attend all PD activities and } \\
\text { encouraged all PD activities in the school. } \\
\text {-Supported the Educational Technology Specialist } \\
\text { and computer science department. }\end{array}$ & $\begin{array}{l}\text {-Financially supported the staff to increase their } \\
\text { ICT knowledge. } \\
\text {-Supported The Computer Science Department, } \\
\text { who, in turn, supported the whole school in ICT } \\
\text { matters. } \\
\text {-Developed a framework for PD activities and } \\
\text { coordinated all PD activities in the school. }\end{array}$ \\
\hline
\end{tabular}

Building a collaborative culture in the school has been identified in the literature as a fundamental practice which is concerned with building the school community, enhancing productivity, and reducing potential conflicts by promoting a collaborative work culture. Principal B (P/B) provided a practical of building collaborative culture in school when she mentioned that:

I asked the geography and science departments to conduct module lessons together because these lessons serve both their subjects. I even managed the timing for them; I asked the geography department to take the first part of the session and the science department to take the second part. I also initiated the collaboration with other schools (Lines: 267-281 P/B).

Principal B's claim highlights the importance she places on building trust, interacting humanely with teachers, and encouraging them to enhance and expand their teaching experiences. Additionally, by being directly involved in organising joint lessons, she illustrated putting theory into practice, to build a collaborative culture within the school.

The future plans of the Principal are indicators of his or her efforts and how he or she sustains ICT changes. Importantly, planning for ICT is also a key practice that leads to effective ICT change sustainability. The following statement illustrates how the Principal B faces such a challenge: 
I plan to transform one classroom as an ICT based model class in our school. We are going to employ technologybased learning activities, and then add more classes (Lines: 299-302.P/B).

The Principal involved the replacement of one class with an ICT-based class, which became the model class for the whole school. The substitution was an effective strategy to experiment with embedding ICT into the school teaching program and to sustain ICT changes. Her direct instructions to the Heads of Department to plan their department's activities were an important part of her ICT planning tactics. The Principal's efforts to sustain the ICT changes, along with the building of a database, establishing a Media Centre, and implementing a texting system, provided insights of the Principal's commitment to keep pace with the ICT development.

Although, both principals acknowledged the importance of effectively linking ICT to pedagogies and providing guidance on how ICT should be used in teaching and learning activities, they faced difficulties encouraging staff to use ICT at an advanced level. Most teachers seemed to use ICT coupled with traditional teaching approaches based on delivery of content. For example, they relied on the use of PowerPoint presentations instead of overheads; or they used CDs to do simple tasks, such as a replacement for an Encyclopaedia. These observations suggest that principals were not providing a clear strategy or framework for embedding ICT in ways that changed teaching practices. Instead, the guidance provided on how ICT should be incorporated into teaching and learning activities was based on his or her prior knowledge, and personal technological, and educational skills.

The participating principals claims were triangulated by teachers perceptions of their principals' leadership practices and were supported by a number of documents that shown principals practices to effectively improve ICT embedding through managing budget, managing maintenance and ICT infrastructure; building shared vision, fostering agreement, motivating staff, setting high expectations; providing individual consideration, providing individual PD opportunities, supervising PD activities, providing an appropriate model; building collaborative culture, building teams, solving problems, connecting school with other schools; providing guidance to link ICT into pedagogy, and sustaining ICT change. Although, interviewed teachers recognised their principals' effort in providing guidance on how should ICT be implemented in teaching and learning activities, they pointed out that they had constrains on how to incorporate ICT in teaching to improve students' ICT capacities and knowledge. They sought further support to be provided on managing ICT in classroom.

To document teaching staff's perception of their principal's leadership practices, teachers from both schools were surveyed using an open-ended questionnaire. The staff recognised the impact their principals' leadership practices had on ICT embedding. They highlighted the effectiveness of the principals' stimulation and encouragement of ICT embedding, which resulted in changing the teaching practices to be more ICT related. For example, a typical response was given by teacher, $(\mathrm{A} / \mathrm{B})$ who stated that:

The leadership practices of Principal have a great role in embedding ICT. These leadership practices promote the use of ICT in many ways, through encouragement, persuasion, and follow-up discussions. The Principal supported and showed interest in ICT. I think that providing more support and financial contributions positively promotes the use of ICT into the school's daily teaching activities (Q/AG/B)

The interviewed teachers identified the leadership practices of their principals (A \& B) as the main motivational force for embedding ICT in the school. For example, Teacher D/A acknowledged that the School, without the Principal's support and attention, would not have reached the current stage of the ICT activities. Similarly, Principal B's support for ICT embedding in the school were corroborated by the teachers, who acknowledged the Principal's motivational strategies to create positive competition among the teachers in the use of ICT.

\section{DISCUSSION}

ICT implementation has been advocated as a mode of transforming education setting to help creating and supporting new economy that depends largely on intellectual productivity (Beach, 2003). The need for further research into effective leadership practices for embedding ICT in schools has been identified by a number of researchers (e.g. Anderson \& Dexter, 2005; Schiller, 2003; Wilmore \& Betz, 2000). These recommendations result 
from the observation that school principals play a fundamental role in leading change and embedding ICT in schools, and that they are responsible for providing opportunities for school growth and development. This study sought to examine how ICT was being implemented in an educational system in transition and in particular the role played by principals in leading this change.

The first aim of this study related to the role of principals in leading and managing change in the uptake of ICT in schools. Embedding ICT, however, required the principal to prioritise ICT requirements, and to provide ICT infrastructure, as well as to minimise the negative impacts from insufficient funding for the ICT embedding process. In the current study, the principals' practices in effectively managing financial matters (the Finance Management component) have a positive influence on the ability and motivation of staff to incorporate ICT into their teaching. Hence, there is the need to link the school budget, pedagogical needs and school activities. These findings are consistent with a number of other studies (e.g., Mendez- Morse, 1992; Mumford \& Licuanan, 2004). For example, the findings confirm Yee's (1999) findings that the principals of ICT-enriched schools (across three nations) played a vital role in managing the school budget. Consequently, support for maintenance equipment and technology is important for ICT embedding success.

Further, the principal is also responsible for ensuring that the central visions (or national agenda) are pursued, must establish a shared vision or align individual teachers' views, beliefs and priorities to that vision. This goal is achieved by the principal facilitating the second broad component, Setting Direction. In the current study, the principals motivated and inspired the school community to promote a mutual understanding and to establish a positive morale. These leadership practices were highlighted by many researchers. For example, the principals' roles in building a shared vision were consistent with Leithwood et al.'s (2006) model of effective leadership practices, and LaBonte's (2005) study who asserted the importance of building a shared vision. Without a clear vision, the teachers tend to suffer from ambiguity and uncertainty, resulting in a failure to change. Moreover, principals' role in motivating staff was spotlighted by a number of researchers as effective leadership practices. For example, Covington (2000) has emphasised the importance of motivating staff during change implementation. Therefore, the second component and its subcomponents are vital leadership practices to facilitate the ICT implementation.

The third broad component, Building Collaboration, was successfully developed through the principals' focus on the organisational relationship structure and the work conditions of the school. The significance of establishing a collaborative culture in school was recognised by a number of studies (Fullan, 2007; Leithwood et al., 2006). For example, Yee (1999) asserts that effective principals build a collaborative culture into their schools to successfully drive change towards its goals and to avoid potential conflicts. Both principals recognised the benefits to the school and the staff of building teams. Effective teams can be organised around five facilitating roles: (a) the speed of completing tasks; (b) the improvement of the collaborative culture in the school; (c) an effective contribution to the achievement of common goals, in this case ICT embedding (Albanese, 1994); (d) the enhancement of the cohorts within the school; and, (e) the permission to allow the staff to participate in the management of the school, which increases their commitment towards the common goal (Holleran, 1997). Therefore, principals need to demonstrate Building Collaboration component and its subcomponents to effectively embed ICT.

The fourth component, Principal Agency, was exhibited by both principals, who lead the ICT embedding process by understanding the why and how of ICT, especially in terms of improving educational outcomes. The findings confirm Jegede et al.'s (2007) findings that there is a significant relationship between ICT competence and the attitudes and practices of an individual. Additionally, when the principal is interested in ICT, then their staff tend to become interested in improving their skills in the use of ICT. Importantly, the principals linked ICT practices to pedagogical issues that must be utilised to enhance student performance (Creighton, 2003). Both principals led and encouraged the teachers, and systematised the processes, so that ICT use became an integral component of the teaching and learning practices. Although, principals A and B demonstrated the ICT skills required by Ministry of Education; and had provided guidance on how to link ICT into teaching and learning practices, both Principals seemed to be lack of essential skills in terms of leading reformed teaching practices. It is observed that principals and teachers were left to rely on their own knowledge and skills to manage, implement, explore, and create use of ICT in teaching and learning practices. This finding is consistent with Alharbi (2012) who revealed that teachers were not provided adequate professional development support, nor were they given clear instructions on how to use 
ICT in the classrooms. Alharbi also found that ICT used at the basic level, was mostly for presentations (as claimed by teachers in other primary schools in Kuwait). LaBonte (2005) posited that embedding ICT in an educational setting needs to go beyond the physical appearance of ICT to focus on the fundamental pedagogical issues that shift how learning is organised. Therefore, principals in Kuwait need to be professionally supported to play learning leader's role and to embed ICT in advanced teaching practices.

The fifth component related to developing staff and it is this aspect that explores the second aim of this study namely, how principals adopted learning leadership roles in supporting staff to adopt ICT in their practices. The two principals exhibited the final broad component of effective leadership practices, Developing Staff; they built ICT capacity and developed the school community socially and professionally. Nevertheless, following Leung et al.'s (2005) use of participatory action research to engage all teachers in capacity building in a Hong Kong school, their strategies were successful in schools confronted with the introduction of ICT, and staffed with teachers whose interest and skills in ICT were limited. It appeared that their encouragement provided the teachers with a sense of competence, a basic need that must be met to make the staff committed and feel confident to positively interact with the ICT embedding (Deci \& Ryan, 2002). The current study also confirms that, in order to meet PD individual needs, the principals must recognise, and reduce their staffs' individual differences in ICT skills and knowledge. Mohammad et al., (2011) acknowledged the need for continuing, non-stop professional development activities to enhance staff skills, especially those needing to incorporate ICT elements into their teaching practices. However, classroom observations indicated many teachers needed further professional development to capitalise on the power of ICT to change pedagogical practices. The current findings corroborate that, at a national level in Kuwait, principals provide the opportunity for individualised development. These results also confirm the findings of Leithwood et al. (2006), Yee (1999), and Mendez-Morse (1992), which are related to effective leadership practice for ICT leading change.

Although, there were some limitations in terms of final outcomes relate to changed or reformed teaching practices, the principals A and B leadership practices were recognised as main driving force toward ICT embedding and contributed to the development of ICT use in schools. Hence, principals who plan to effectively lead an ICT embedding processes within schools need to use the revised model of effective leadership practices as a guide. The model is comprised of three major approaches and five leadership components, outlined below and shown in Figure 1. The current study has, therefore, made a major contribution to the provision of empirical evidence in relation to leadership practices of school principals and their impact on ICT change. The development of the model, presented in Figure 1, has been grounded in the both the literature review and the findings from the current study.

The new and improved effective leadership practices model for ICT embedding places an emphasis on the principals' practices related to their five broad leadership practice components and subcomponents. Specifically, this involved three major strategies that influenced the impact of the principals' leadership practices, namely: (a) encouragement for teaching staff to behave in the desired way; (b) support to meet the material and human needs of teaching staff; and (c) provision of instructions and guidance for teaching staff in how and why such behaviours and practices should be performed. These three strategies formed the base of the five effective leadership practice components used as the framework in the current study.

The five leadership practice components and subcomponents are shown in Figure 1 below. In the Kuwaiti context, these three strategies need to be demonstrated with the focus on individual staff. Individual teachers appeared to neither respond to nor appreciate the principal's support, encouragement, and provision of instructions and guidance at the school level. Instead, individual teachers appreciated and responded to actions that were undertaken for them individually. This revised model extended and improved the initial framework to accommodate and highlight the strategies that used by the principals to influence on staff attitudes, practices, and behaviours to embed ICT. 


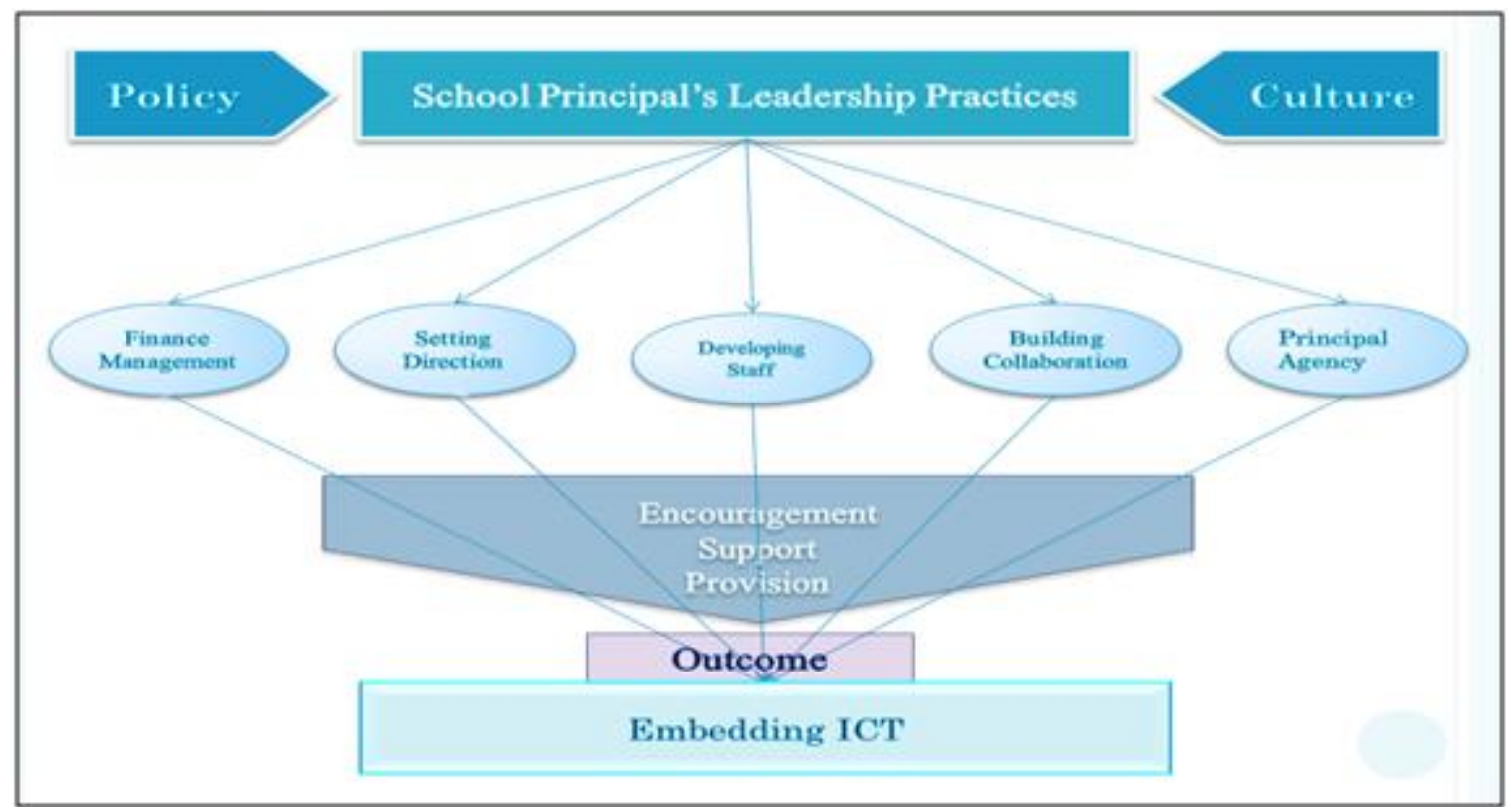

Figure 1 Effective Leadership practices for embedding ICT into Schools

Since the policies and culture have an impact on the principals' roles (Fullan, 2007), these factors have been acknowledged and included in the model of effective leadership practices for embedding ICT. Such an impact is the Kuwaiti Ministry of Education's regulations and centralisation policies. To successfully implement this model, however, the Kuwaiti Ministry needs to reconsider the regulations related to school principals' responsibilities. For example, the principals need to have autonomy to freely lead and manage the school.

\section{CONCLUSION}

The enhancement of human capital to meet modern day demands of a knowledge economy, and equip the new generation's capacity to meet the challenges of the 21 st Century has become a priority. This change is particularly necessary in economies typical of countries, such as Kuwait, which have been dependent on the exploitation of non-renewable natural resources. Therefore, ICT has been seen as a useful alternative to create new productive sectors that contribute to the development of cognitive capacities of citizens and skill to keep pace with global development.

An analogy for the ICT embedding process is an irrigation channel, which is full of water. The principals are the sluice gates that ensure a balanced and controlled flow of water or movement. Hence, the principal's leadership practices are essential skills that are needed to lead, regulate and manage the ICT embedding process. Thus, three major strategies (encouragement, support, and provision) form the background structure of the model upon which these practices are displayed. Further, the five components interact dynamically as the leadership roles are undertaken by the principals; their characteristics are related and overlap (as shown in Figure 1). Indeed, the data revealed that effective leadership practices are influential factors in planning ICT implementation into schools. Therefore, school principals should be professionally supported to effectively respond to ICT introduction policy. However, while such support needs to be aligned with the elements shown in Figure 1, they also need opportunities to build their capacity to be "learning leaders" as advocated by duFour and Marzano (2009).

\section{AUTHOR INFORMATION}

Mohammed Al Sharija, BEd (PAAE, Kuwait); MEdAdmin (Amman Uni, Jordan); PhD (QUT, Brisbane). Mohammed is a teacher at the Ministry of Education in Kuwait. He has more than ten years of teaching experience in Kuwait. His research interests include staff professional development, ICT in education, and leadership. E-mail: mohammed.alsharija@connect.qut.edu.au (Corresponding author) 
James Watters, BSc Hons, (UQ); Med Hons (UNE); PhD (Griffith U). James is an Associate Professor in Education at QUT, Brisbane. His research interests include staff professional development, science education and education of gifted students.

\section{REFERENCES}

1. Albanese, R. (1994). Team building process: Key to better project results. Journal of Management in Engineering, 10(6), 36-44.

2. Alharbi, G. (2012). Primary school teachers' perceptions regarding ICT usage and equipment in Kuwait. Journal of International Education Research (JIER), 8(1), 55-62.

3. Anderson, R. E., \& Dexter, S. L. (2000). School technology leadership: Incidence and impact. teaching, learning, and computing: 1998 National Survey, Report: 6. Retrieved August 12, 2009, from http://escholarship.org/uc/item/76s $142 \mathrm{fc}$

4. $\quad$ Beach, D. (2003). From teachers for education change. European Educational Research Journal, 2(2), 203227.

5. Covington, M. V. (2000). Goal theory, motivation, and school achievement: An integrative review. Annual Review of Psychology, 51(1), 171-200.

6. $\quad$ Creighton, T. B. (2003). The Principal as technology leader. Thousand Oaks, CA: Corwin Press.

7. De Ferranti, D., Perry, G. E., Lederman, D., \& Maloney, W. E. (2002). From natural resources to the knowledge economy: Trade and job quality. Washington, DC: World Bank Publications.

8. Deci, E. L., \& Ryan, R. M. (2002). Handbook of self-determination research. Rochester, NY: University of Rochester Press.

9. DuFour, R., \& Marzano, R. J. (2009). High-Leverage for principal leadership. Educational Leadership, 66(5), 62-68.

10. ECDL Foundation. (2008). International computer driving license (ICDL). Retrieved October 30, 2008, from http://www.ecdl.org/publisher/index.jsp

11. Ely, D. P. (1990). Conditions that facilitate the implementation of educational technology innovations. Journal of Research on Computing in Education, 23(2), 298-305.

12. Ely, D. P. (1999). Conditions that facilitate the implementation of educational technology innovations. Educational Technology, 39(6), 23-27.

13. Fullan, M. (2001). Leading in a culture of change San Francisco, CA: Jossey-Bass.

14. Fullan, M. (2007). The new meaning of educational change (4th ed.). NY: Teachers College Press.

15. Gichoya, D. (2005). Factors Affecting the Successful Implementation of ICT Projects in Government. Electronic Journal of e-Government, 3(4), 175-184.

16. Harris, J., Mishra, P., \& Koehler, M. (2009). Teachers' technological pedagogical content knowledge and learning activity types: curriculum-based technology integration reframed. Journal of Research in Technology Education, 41(4), 393-416.

17. Holleran, D. J. (1997). Team building in an elementary school: A descriptive case study (Ed.D.) Virginia Polytechnic Institute and State University, United States Virginia. Retrieved from http://gateway.library.qut.edu.au/login?url=http://search.proquest.com/docview/304372846?accountid=133 80. ProQuest Dissertations \& Theses (PQDT) database.

18. Jegede, P., Dibu-Ojerinde, O., \& Ilori, M. (2007). Relationships between ICT competence and attitude among some Nigerian tertiary institution lecturers. Educational Research and Review, 2(7), 172-175.

19. Kozma, R. (2005). ICT, education reform, and economic growth. Retrieved October 19, 2009, from http://www.cendoc.colombiadigital.net/cendoc docs/Doc\%2010323\%20(ICT,\%20Education\%20Reform,a nd\%20Economic\%20Growth).pdf

20. Kozma, R. (2010). Relating technology, education reform, and development. In B. McGaw, E. Baker, \& P. Peterson (Eds.), International Encyclopedia of Education. Amsterdam: Elsevier.

21. LaBonte, R. (2005). Leadership and educational technologies: Leading the charge for e-learning in British Columbia schools. (PhD thesis). The University of British Columbia, Canada. Retrieved from ProQuest Dissertations and Theses (AAT NR10524). 
22. Leithwood, K. A., Day, C., Sammons, P., Hopkins, D., \& Harris, A. (2006). Successful school leadership: What it is and how it influences pupil learning. Retrieved March 26, 2009 from http://www.nationalcollege.org.uk/docinfo?id=17409\&filename=successful-school-leadership-fullreport.pdf

23. Leung, K. P., Watters, J. J., \& Ginns, I. S. (2005). Enhancing teachers' incorporation of ICT in classroom teaching. Paper presented at the 9th Annual Global Chinese Conference on Computers in Education.

24. Levin, T., \& Wadmany, R. (2008). Teachers' views on factors affecting effective integration of information technology in the classroom: Developmental scenery. Journal of Technology and Teacher Education, 16(2), 233-263.

25. Ma, S. P. (2003). How a principal's role influences ICT implementation in a Hong Kong primary school (doctoral dissertation). Retrieved from HKU Theses Online (ID b2971785)

26. Mendez-Morse, S. (1992). Leadership characteristics that facilitate school change. Retrieved September 20, 2011, from http://www.sedl.org/change/leadership/character.html

27. Ministry of Education (2008). The national report development of education in the state of Kuwait 20042008. Paper presented at the $48^{\text {th }}$ session of the International Conference on Education, Geneva.

28. Ministry of Education . (2002). ICDL decision Retrieved June 12, 2007, from http://www.moe.edu.kw/schools2/hawally/primaryschools/boys/gmschool2006/icdl_decesion.htm.

29. Ministry of Education. (2007). Education plans. Kuwait: Ministry of Education.

30. Mohammad, H., Manssour, N. \& Wegerif, R. (2011). Kuwait's future schools: Teachers' perspective on ICT integration in classroom practice. In M. Koehler \& P. Mishra (Eds.), Proceedings of Society for Information Technology \& Teacher Education International Conference 2011 (pp. 2598-2603). Chesapeake, VA: Association for the Advancement of Computing in Education (AACE).

31. Mumford, M. D., \& Licuanan, B. (2004). Leading for innovation: Conclusions, issues, and directions. Leadership Quarterly, 15(1), 163-171.

32. Rogers, E. M. (2003). Diffusion of innovations (5th ed.). New York: Free Press.

33. Saunders, A., Brynjolfsson, E., LoBue, A. M., Meyer, D., \& Samuel, C. (2007). Information technology, productivity and innovation: Where are we and where do we go from here? Unpublished working paper, MIT Sloan School.

34. Schiller, J. (2002). Interventions by school leaders in effective implementation of information and communications technology: Perceptions of Australian principals. Technology, Pedagogy and Education, 11(3), 289-301.

35. Tondeur, J., Devos, G., Van Houtte, M., van Braak, J., \& Valcke, M. (2009). Understanding structural and cultural school characteristics in relation to educational change: The case of ICT integration. Educational Studies, 35(2), 223-235.

36. Wilmore, D., \& Betz, M. (2000). Information technology and schools: the principal's role. Educational Technology \& Society, 3(4), 12-19.

37. Yee, D. L. (1999). Leading, learning, and thinking with information and communication technology (ICT): Images of principals' ICT leadership. (PhD thesis). University of Calgary, Canada. Retrieved ProQuest Dissertations \& Theses (PQDT). (304495047)

38. Yin, R. K. (2009). Case study research: design and methods (4th ed.). Thousand Oaks, CA: Sage Publications. 